\title{
加硫ゴム製品の機器分析方法とその問題点（第 7 講）
}

\section{ゴム補強用繊維の評価}

\author{
高木康夫 ${ }^{*}$ - 多田晋作 ${ }^{*}$ ・吉田五月生 ${ }^{*}$
}

\section{1. 序論}

繊維を補強材とする加硫ゴム製品 (FRR) には，タイ ヤ，Vベルト，コンベヤベルト，ゴムホースなどがあり， ほとんどの場合繊維材料はコード，スダレ又は織物の形 で使用される．短纎維又はホイスカーをそのままゴム中 に混合する方法がいくつか紹介されており，実用例とし てVベルトの底ゴム用 $\mathrm{FRR}^{86)}$ があるが，前者に比べる と, 工業的に大量に使用されるには至っていない，

補強材として用いられる瀻維は古くから強カレーヨ ン, ナイロン, ポリェステル, ビニロン, ガラス, スチ 一ルなどの範囲に及んでいるが，その役割は，第一に荷 重を支えること，第二に形態を保持することである。一 般に過酷な使用条件に耐える必要性と製造プロセスでの 工程の安定性の要求から, 用途によって多少の違いはあ るが, 繊維の性能に対する要求は厳しく, 原料から最終 製品に至るまでの多くのステップで繊維製品の評価が問 題にされる.

ゴム補強用繊維の評価は 3 段階に分けて考える必要が ある。

(1) 原料としての繊維の評価(原料繊維, コード)

(2) 中間加工品及び加工工程中での評価

（3）製品使用特性との関係における評価

それぞれの技術内容に応じて, 繊維の一般特性評価, 化学分析, 高分子機器分析, インラバーテストなどが利 用されている. 個々の測定方法の原理や装置の詳細につ いては，既に多くの成書や便覧類 ${ }^{1)-8)}$ によとめられてお り，ここではこれらの方法の説明は割愛する.

また FRR の代表的製品であるタイヤ用の繊維の最適 化の立場から見た繊維特性の考え方に関しては武山らの 総説 ${ }^{9) 10)}$ にくわしい.

\footnotetext{
*東レ株岡崎工場技術部

(宁444 岡崎市矢作町字出口 1 番地)
}

本稿ではこれらとの重複を避け，緎維の評価手法を軸 にして,FRR 中での繊維の挙動をながめてみることにす る.

\section{2. ゴム補強用緎維に要求される性能}

加硫ゴム製品の要求特性から，どのような性能あるい は特性がその補強用繊維について問題とされているかを 考えてみよう。

多くの場合, 繊維はコード又はその集合体(スダレや 織物)の状態で接着剂与付と寸法安定化のための熱 処 理 (いわゆるディッピング)を施こされた後, 製品の形状に 成形, 加硫される. 特に有機繊維では, ディッピング工程 でいかにその形態の安定化が行われ，成形加硫工程で寸 法変化が少なくてすむかということがまず問題となる.

すなわち繊維の熱収縮挙動が製品の加工工程で重要とな る.

製品中での繊維の役割は主に補強と形態安。定化であ り，そのため強さと引張応力が最も重要視される. 製品 はその使用中に複雑な繰返しの応力とひずみを受け，そ れに対して, 補強繊維も繰り返し伸長, 圧縮疲労を経験 するが, 繊維がこの疲労に充分耐えて, 永く強さ及び形 態を保持することが, 初期の強さとともに重要となる.

加硫ゴム製品中での繊維の疲労は単に繊維自体の粘弾 性的な特性のみならず, 纎維一ゴム界面(接着性), 繊維 間摩擦, より数, 熱, 酸素, 水, アミンなどによる化学 的劣化などが関係する非常に複雑な現象であり，これら のいろいろの特性を充分は握する必要がある. 水やアミ ンなどによる化学劣化は, 製品の使用中だけでなく, そ の製造工程(加硫工程) でも問題となり得る.

繊維の疲労の問題は繊維の粘弾性特性, 特に発熱と深 い関係にあり，このような特性を知ることが重要と考え られる。 また, 発熱が起こった場合, 繊維がいかにこれ に耐え得るか(耐熱性)がゴム補強用㵶維としての性能を 
左右する.

タイヤにおいては，上述のような製品要求特性のほか に，「乗り心地」や「操縦安定性」が問題とされ，これ らは主として瀻維の弾性率に関保しているといわれる。

また，長時間張力下にさらされるコンベアベルト，V ベルトなどでは繊維のクリープ特性も重要なファクター となる.

以上のように，ゴム補強材としての繊維は，用途によ って多少の違いはあるものの，各種性能を満足すること が必要であり,これらの性能の把握はその性能の改善に とっても有益である，以下の節で，ゴム補強用纎維の各
特性の試験を，できる限りゴム製品の特性との関連にお いて述べてみたい.

なお，加硫ゴム製品の中の代表的なものと考えられる

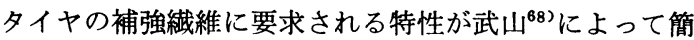
潔にまとめられているので，表 1 に引用した。

\section{3. 㘍維・コードの基本特性試験法}

ゴム補強材として用いられる繊維は，その用途に要求 される特性に応じて選択され，また用途によっては，加 撚，ヒートセットあるいはゴムとの接着性能を付与する ための接着剤処理が行われ，㵶維に対する要求特性を付

表 1 タイヤ特性とコード特性

\begin{tabular}{|c|c|c|}
\hline タイヤ特性 & 好ましいコード特性 & コード素材間の比較 \\
\hline \multicolumn{3}{|l|}{ （製造工程上の問題） } \\
\hline $\begin{array}{l}\text { すだれの耳つり，たるみ，ルー } \\
\text { ズコード }\end{array}$ & 吸湿収縮小，遅延回復小 & レーヨン, ナイロンで発生 \\
\hline $\begin{array}{l}\text { 成型性 } \\
\text { 加硫時 }\end{array}$ & 柔軟性 & スチールで問題，太デニールコードで注意 \\
\hline uniformity（形状，寸法） & 収縮小(吸湿及び熱) & ナイロンの欠点 \\
\hline 加硫時強力低下 & 高融点，低水分 & ナイロン 6 の欠点 \\
\hline 内部欠陥の発生 & 柔軟性, 空気透過性大 & \\
\hline コードのタイヤ内面への落込み & 熱収縮小 & （チューブレスタイヤで特に要求大） \\
\hline \multicolumn{3}{|l|}{ （耐久性，安全性） } \\
\hline 耐疲労性(圧縮一伸長) & ヨリ数の最適化など & ナイロン>ポリエステル>レーヨン \\
\hline 耐化学劣化性 & 加水, 加アミン, 酸化劣化小 & ポリエステルの加水, 加アミン分解 \\
\hline 耐衝撃性 & 衝撃破壊エネルギー大 & ナイロン良好 \\
\hline $\begin{array}{l}\text { セパレーション } \\
\text { (プライ, トレッド, エッヂ) }\end{array}$ & 接着性大，柔軟性 & $\begin{array}{l}\text { 以前, ポリエステル・スチールの欠点であ } \\
\text { った. }\end{array}$ \\
\hline 溝割れ抵抗 & 高ヤング率, 低クリープ性 & \\
\hline 耐発熱性* & 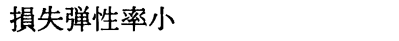 & スチール，Armid 良好 \\
\hline $\begin{array}{l}\text { 耐水性(カットからの吸湿) } \\
\text { 耐パンク性 } \\
\left(\begin{array}{l}\text { (クギぶ破壊状態 } \\
\text { 抗 }\end{array}\right)\end{array}$ & 低水分, 耐蒸熱性大 & $\begin{array}{l}\text { レーヨンの湿潤強力低下，スチールのサビ } \\
\text { スチール良好 }\end{array}$ \\
\hline 高温特性(強力, 魝性) & 高融点, 高ガラス転移点 & \\
\hline \multicolumn{3}{|l|}{ （乗心地） } \\
\hline 良路での (Uniformity) & 低収縮 & \\
\hline 悪路での** & ヤング率小 & ガラス, スチールで問題 \\
\hline フラットスポット & ヤング率大, 高ガラス転移点 & ナイロンで問題 \\
\hline \multicolumn{3}{|l|}{ （操繸性，安全性） } \\
\hline コーナリング・パワー* & 高ヤング率(トレッド剛性大) & $\begin{array}{l}\text { ナイロン<ポリエステル，レーヨン<スチ } \\
\text { ール, Aramid }\end{array}$ \\
\hline 復元トルク & 高ヤング率(トレッド剛性大) & 同上 \\
\hline \multicolumn{3}{|l|}{ （経済性） } \\
\hline 燃料消費量* & 損失弾性率小(発熱小) & スチールの特徴 \\
\hline トレッド摩耗* & $\begin{array}{l}\text { 高ヤング率(トレッ剛性大)など } \\
\text { 発熱小 }\end{array}$ & スチールの特徴 $\left\{\begin{array}{l}\text { Aramid } \\
\text { 大 }\end{array}\right.$ \\
\hline $\begin{array}{l}\text { リキャップ性(大型タイヤ)* } \\
\text { コード使用量, ゴム使用量 }\end{array}$ & 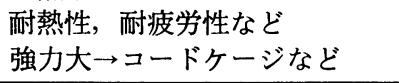 & スチールの特徴 \\
\hline
\end{tabular}

*ラジアルタイヤの長所. **ラジアルタイヤの欠点 
加させる必要がある。このように個々の用途に応じた要 求特性を, 満足しているか否かを判定するための評価が 必要となる。

本章では，原料としての㵶維，コードの試験方法およ びその役割と繊維の挙動とについて概説する.

なお, 加硫ゴム中から補強用纎維を取り出し, 基本特 性を評価するときも本章の方法に準じて試験すればよい が，サンプリングは，例えば次のように行うと良い'11).

1）加硫ゴムを，可能なかぎり多く鋭利な刃物でコー ドを傷付けないよう注意深く取る.

2）ベンゼンあるいはトルエンなど，コードの特性に 影響しないような溶媒に浸せきする。

3）浸せき 4 時間後にコードから残りのゴムを手で除 去する.

\section{1 織度, より数・水分率など}

繊維の分析以前に把握すべき特性であり, 纎維, より 数，水分率などそれぞれ JIS ${ }^{12) 14}$ に定められた方法がと られる，繊維素材によっては，品質への影響があり，試 験方法への配慮もみられる(13)14)。特にレーヨンコードの 場合, 平衝水分状態と絶乾状態とではコード物性が大き く異なる．またナイロン及びポリェステルの場合，加硫 中などにコードの吸湿及びゴム中の水分の影響を受けコ 一ド強力劣化をきたす場合があり，品質への水分の影響 は，品質管理上及び製品の性能上重要な要因である.

繊維素材と FRR の特性へのより数の影響について は, 多くの研究 ${ }^{15)}$ がある.

\section{2 強伸度 $\cdot \mathbf{S}-\mathrm{S}$ 曲線}

緎維あるいはコードの強伸度測定には, 次に示す 3 種 の引張試験機が用いられる

a. 定速移動型(Constant Rate of Traverse)

b. 定速荷重型(Constant Rate of Load)

c. 定速伸張型(Constant Rate of Specimen Extension)

定速移動型(CRT) の簡単なものは, ショッパー式であ り，定速荷重型 $(C R L)$ で最も多く使用されるものは，傾 斜面式で，大型ではスコット式がある。一方定速伸張型 (CRE) は，上記の方法に次いで急速に発展した方法で， データの自動処理機能を付加したものも多く利用される ようになった.

\section{3 ヒステリシス}

FRR が繰り返し変形を受けるとき,構成材料のヒステ リシス・ロスによって温度上昇が起こり，耐久性を低下 させることがある．またタイヤのころがり損失の原因に なって走行抵抗に寄与するところから, 補強緎維材料の
ヒステリシスが問題にされる。

ヒステリシス・ロスが比較的大きいポリエステルのタイ ヤコードに関する研究が多く17)，例えば， Powers ${ }^{18)}$ は Instron Environmental Chamber System にオシロスコー プを組み合せた装置により，バイアストラックタイヤの 負荷回転中のコード変形を機械的にシミュレートして, ポリエステルタイヤコードのヒステリシスをとらえ，コ 一ドの処理条件によるヒステリシス・ロス改良の可能性 を示唆した.

\section{4 寸法安定性}

繊維材料の寸法安定性の評価特性としては, 初期引張 抵抗度(モジュラス)，グロース，クリープ，ガラス転移 点及び熱収縮率がある，基本的試験方法に”づいては， $\mathrm{JIS}^{14)}$ 及び ASTM ${ }^{13)}$ などに記載されているので省略する が，これらの項目は，FRRにおける寸法安定性を決定す

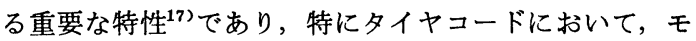
ジュラス，グロース，クリープ及びガラス転移点は，夕 イヤの安定性, フラットスポット, トレッド摩耗及び発 熱に影響するので厳しい管理が行われる.

一方熱収縮率は，例えばタイヤの場合，加硫 $\left(160^{\circ} \mathrm{C} \sim\right.$ $\left.170^{\circ} \mathrm{C}\right)$ 時の収縮は，タイヤサイズのユニホーミティに影 響するので，低収縮率化の要求が強い19).

\section{5 伸張及ひ屈曲疲労}

疲労試験の方法としては, 次のものがある.

1) 伸張疲労を目的として, 繊維の長さ方向に周期的 伸張を繰り返す方法 ${ }^{20}$

2）無張力下で単繊維に biaxial rotationを与える方法 21)

3）一定荷重を吊り下げた糸にローラにより，繰り返 し屈曲を与える方法 ${ }^{22}$

4) 回転する 2 枚のギヤーの間で屈曲を与える方法 ${ }^{23)}$

5）一定荷重下で $90^{\circ}$ 屈曲を繰り返す方法.

FRR の中では, 特に耐疲労性への要求が強いタイヤコ 一ドについて報告が多く, 疲労試験方法は, 大別して,

1) 繊維及びコードの状態で行う方法

2）ゴム中にコードを包埋した状態で行う方法 の 2 方法がある. 後者の方法については, 4 章で述べる ことにして，ここでは前者の疲労性について記述する.

繊維, コード状態における代表的試験方法をあげれ ば，以下のとおりである.

\section{a. 伸張疲労型コード試験法}

i Goodrich Cord Tension Vibrator ${ }^{24)}$

ii Du Pont Dynamically Balanced Tester ${ }^{25)}$

iii U.S. Rubber Fatigue Tester ${ }^{26)}$ 
b. 屈曲伸張疲労型コード試験法

1 Goodrich Rotor Flexer ${ }^{27)}$

次に, $2 \sim 3$ の例をあげて説明する.

Lyons $^{20)}$ は, 繰り返し伸張疲労試験を行い, 図 $1^{28) 29)}$ のように疲労性は, ナイロン>ポリエステル>アクリル >ビスコース・レーヨンの順に悪くなる結果を得た.

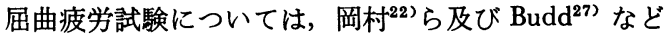
の研究例がある.

\section{6 街撃強度}

繊維及びュードの衝撃強度は，タイヤ及びベルトなど の性能上重要な特性であり, 多くの研 究 ${ }^{30), 31)-36)}$ があ る. 衝撃強度の試験方法にも多くの方法がみられるが, 機構的に分類すると次の 3 種類になる.

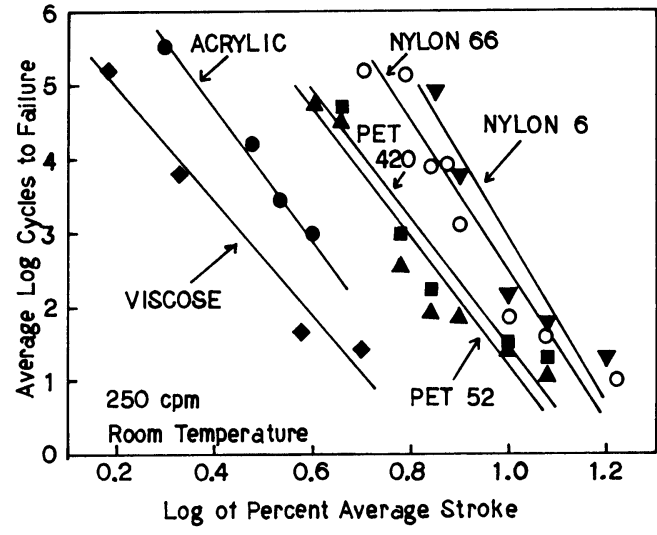

図 1 各種繊維の繰り返し伸長疲労性 ${ }^{2829}$ ) a. 横衝擊試験法 ${ }^{30), 37)-40) ~}$

b. 振子型試験法 ${ }^{30)-32 \text { ) }}$

最もよく用いられている方法で，JIS ${ }^{14)}$ にも規定され ている.

c. 高速引張試験法 ${ }^{30), 33)-6) ~}$

高速変形の与え方，変形と力の記録，ふん囲気設定な

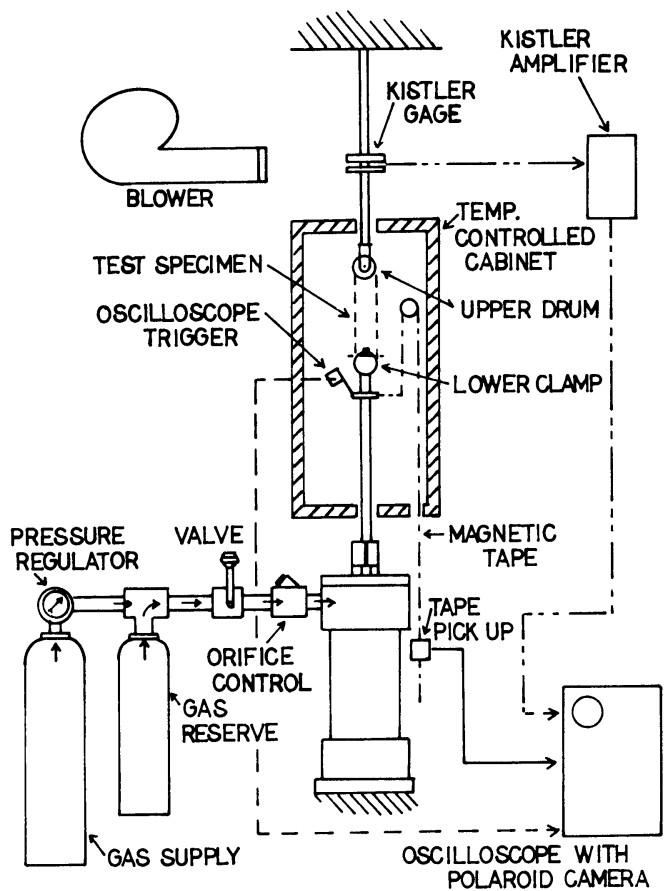

図 2 Lothrop $^{35)}$ による高速引張試験機の概略図

表 2 レーヨンおよびナイロン処理コードの破断特性（引張温度および速度依存性）

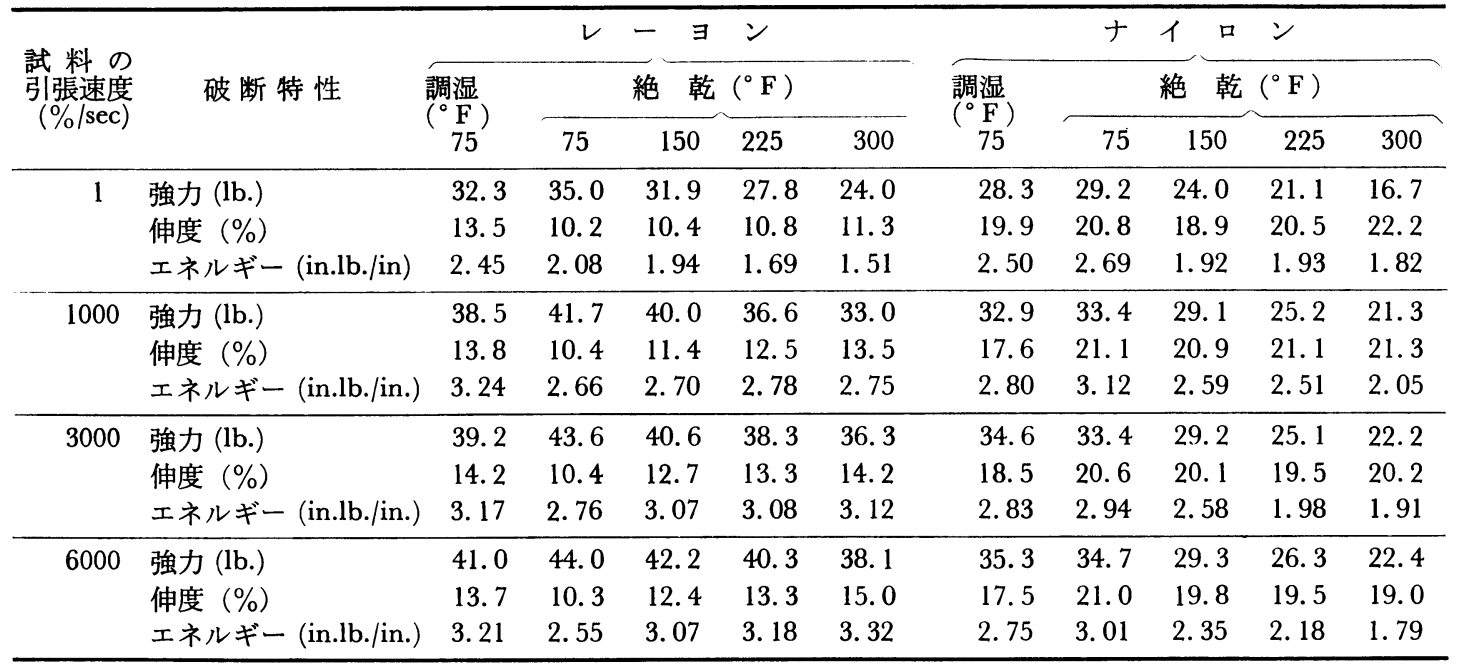


どに工夫をこらした研究例も多( ${ }^{31)-36)}$. 一例として, Lothrop $^{35)}$ は，高温零囲気中でも測定出来る図 2 の方 法 により，レーヨンとナイロンについて $75 \sim 300^{\circ} \mathrm{F}, 1 \sim$ $6000 \% / \mathrm{sec}$ の変形速度下で実験し, 表 2 の結果を得た.

\section{7 耐熱性}

FRR は, 高温ふん囲気中で長時間使用される場合があ り，またタイヤの場合，走行中ヒステリシス・ロスによ る発熱のため, トラックタイヤの場合一般に $120^{\circ} \mathrm{C}$ を゙ 昇温するといわれている41)。このように補強用繊維の耐 熱性, 特に強力保持性は, FRR の耐久性を左右する実用 上重要な特性である.

耐熱性試験法として JIS ${ }^{14)}$ では， $180^{\circ} \mathrm{C} \times 2$ 時間ある いは 4 時間, $160^{\circ} \mathrm{C} \times 5$ 時間, $140^{\circ} \mathrm{C} \times 24$ 時間の条件のら ち一つを選び, 加熱後, 絶乾状態あるいは標準状態で放 置後強力を求める. 一方 $\mathrm{ASTM}^{13)}$ では $135^{\circ} \mathrm{C}$ 加熱ふん囲 気中で強力を求める.

各種繊維素材の耐熱性データ ${ }^{17)}$ ，耐熱性改良手段とそ の効果については, 引用文献 ${ }^{42)-44)}$ を参照されたい.

\section{8 素材の同定}

素材同定の方法としては, 各種の方法があり， JIS ${ }^{46)}$ 及び ASTM ${ }^{47)}$ では, 纎維の表面及び断面観察, 比重, 複 屈析の測定, 試薬テスト, 燃焼テスト及び I Rスペクト ルなどの組合せによる多くの方法を規定している.

\section{4. 加硫ゴム中包埋緎維の試験法}

FRR 中での繊維の挙動は, 複雑な要素を含み, 繊維材 料単独での特性評価だけでは, FRR の性能との対応を論 じるのに不十分なことがある．製品の使用特性と関係ゔ けやすいモデル的な条件を設定し，ゴム中包埋状態で様 々の刺激を加えて㵶維材料の変化を見る試験方法が一般 的である.

\section{1 接着性}

タイヤ，コンベヤベルト及びトランスミッションベル トなどは，過酷な条件で利用されるため，非常に高レべ ルの接着性が要求される。一方ホース類, ゴム引布など は，適度の接着性が達成されれば良いが，水や薬剂の影 響下の接着性を重視されることが多い.

接着性の試験方法として, JIS ${ }^{48))}$ では, はく離テスト を, ASTM ではHテスト及びUテスト ${ }^{49)}$, 平ベルト及び ゴム引布については，はく離テスト ${ }^{50)}$ を規定している. 一方スチールコードについては，引抜きテスト及びはく 離テスト ${ }^{511}$ を規定している.このよらに接着性の評価 は，実験室的な方法と実地テストとが実施される．接着 性は, FRR の使用中に次第に低下寸るから，接着性の疲
労について，その変化を厳密にはシミュレートして試験 する必要がある。この要求を満たすために静的試験及び 動的試験が発達し, 実験室的に評価 ${ }^{54)}$ が試みられている ものの満足な試験方法がない。

近年，ラジアルタイヤ及びスチールコードタイヤの急 速な発展に伴い, 特に動的接着性の評価及びスチールコ 一ドの接着性に関する研究報文が多い. 例えば,

Langevin $^{52)} ら$ は, Firestone Flexometerにより図3の方法 でスチールコードの動的接着性について試験し，タイヤ テストと良い相関のあることを報告している。 また静的 テストについては，Hテストの改良及びスチールコード について ASTM 法の改良などの研究 ${ }^{53)}$ が見られる.

ポリエステルの場合, ゴム中のアミン化合物によりコ 一ドが劣化を受け接着性及びコード強力が低下する問題 があり, 高温長時間ゴム中で熱処理(あるいは加硫)し て, 処理前後の接着力を比較するなどの評価 ${ }^{43)}$ む行われ ている.

\section{2 疲労寿命}

FRR の中で, 疲労が最も重視されるのはタイヤコード である、したがって，ここにはタイヤコード用の疲労性 試験法を中心に述べるが, ベルトなどへの応用も可能で ある。

疲労性試験方法は，大別すると次の 3 種に分類 ${ }^{14), 55)}$ できる。

詳細については，総説早,10)もあるので省略する.
a. Scott 型耐もみ摩耗試験機 56 )

b. 圧縮一曲げ疲労型

i Firestone Compression Flexing 疲労試験法

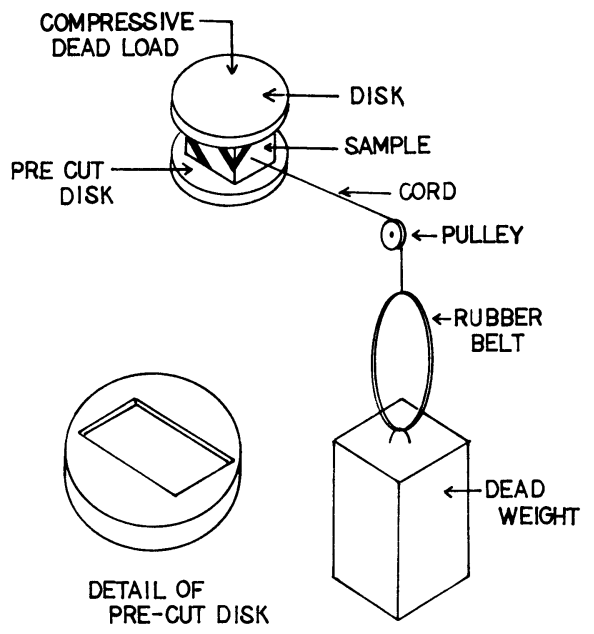

図3 Firestone Flexometer ${ }^{52)}$ 
is De Mattia 疲労試験法

iii Dunlop 疲労試験法

c. 伸張一圧縮疲労型

1 Mallory Tube 疲労試験法

ii U.S.Rubber Tube 疲労試験法

iii Goodrich Disk 疲労試験法

上記疲労試験法の 5 ち, Scott 型耐もみ摩耗試験機は 一般の布及びゴム引布などに用い，一定回転した後の外 観, 強度低下で評価するよ $5 \mathrm{JIS}^{56)}$ で規定している.

Firestone Compression Flexing 痩労試験 機について も，Vベルトなどへの応用規定 ${ }^{57)}$ が見られる.その他， 自動車用ブレーキホース用の疲労試験法が JIS ${ }^{58)}$ で規定 されている.

Kenyonら ${ }^{11}$ は, タイヤコードにより Firestone, Goodrich, Dunlop 及び Malloryの 4 種の方法について比較 し, Mallory Tube Test でのチュープ剛さの影響など, 疲労性の実験室的な試験方法の改良について検討した.

Forster ${ }^{58)}$ は, 乗用車用タイヤの疲労性を評価する方 法として SCEF (Shear, Compression, Elongation, Flex) Fatigue Tester を考案し, 各種要因と疲労性の関係を検 討し，一般に確立されているタイヤの動的解析結果及ぴ 性能と一致する結果を得たと述べている.

\section{5. 物理化学的評価法}

3，4 章に述べた評価方法は緎維素材特性の直接的は 握を行うものである。これらの特性とFRR の特性とを 現象論的に整理することにより繊維素材の最適化がなさ れるのが一般的であるが, 更に詳細な解析や繊維素材の 改質を行らには対象とする現象のメカニズムに踏みこむ ことになる. 分析手法もまた以下のよ5な物理化学的手 段が必要になる。

\section{1 形態観察}

繊維の形態観察には古くから光学顕微鏡か゚使われ，緎 維の断面や側面の形態的特徵をとらえるためにさまざま の工夫が加えられて来た ${ }^{600}$. 近年の走査型電子顕微鏡の 普及によって, 織物構造から単繊維表面のごく一部に至 る幅広い寸法範囲で，焦点深度の大きい立体的な画像が 容易に見られるよ5になり ${ }^{61}$, 繊維の形態に関する膨大 な情報が蓄積されつつある.

FRR の使用寿命との関連において,くりかえし変形に よる疲労破壊のメカニズムが議論されることが多い、こ の種の現象の解析にあたっては形態的変化の確実な追跡 が出発点になり，顕微鏡を駆使して変形の様式や破断端 の形態を観察する試みが多くなされている.
Pattersonら ${ }^{62)}$ はタイヤ中で疲労破壊したナイロン66コ ード構成繊維の破断端が繊維軸に対して $25^{\circ}$ の角を成す ことを発見し，ポリエステルとナイロン 6 繊維について も同様なパイアスカットがおこること認めて, 引張切断 とは異ったメカニズムによる破壊であると主張した，彼 等は更に進んで透明ゴム中に包埋したコードがくりが し伸長・圧縮を受ける際の形態変化を追跡して, フィラ メントの届曲及び座屈とコードのよりの関係を論じた 63)、また詳細な形態観察の積み重ねから，疲労破壊が緎 維の圧縮部表面に発生する亀裂とその伝播に起因すると 推論している.

宮本ら ${ }^{64) 65}$ は同様の問題を取り上げ，疲労過程で発生す る繊維表面の Kink bandについてくわしく観察して，疲 労破壊に至るプロセスを Kink bandの発生・生長・クラ ックへの発達の 3 段階に分けて説明している.

単繊維におこる疲労現象をモデル的に解析した例とし て, 石崎ら ${ }^{66)}$ はPET 剛毛糸をくりかえし屈曲すると圧 縮側に繊維軸と $45^{\circ}$ を成す亀裂が発生し生長することを 認めた. 5.2 デニールのPET 単繊維に繰り返し変形を与 えると，断面で見ると放射状のき裂が長さ方向には，ら せん状に連続して発生するとい5観察結果もある ${ }^{67)}$.

図 4 は実験室的タイヤ走行テスト後, 取り出したナイ ロン繊維を引張破壞した場合の，典型的なバイヤス破断 端の形状の光顕写真, 図 5 は同様の試験後取 り出した PET 繊維のフィブリル状変形を示す SEM写真である 68)

\section{2 分子量及び分子量分布}

加工工程やゴム製品の使用時に受ける刺激によって緎 維の性能が低下する原因を推定するにあたり，分子量の 変化の有無を調べて判断材料にすることが一般的であ る. 機械的刺激による分子鎖の切断や，加熱による縮合 や架橋の進行のよ5な複雑な現象を考虑外に置いてはな らないか゚，明白な分子量低下があるときには化学劣化 が，そ5ではないときには化学的変化を伴わない構造変 化か゚起こっていると考えてよい，この意味で，分子量測

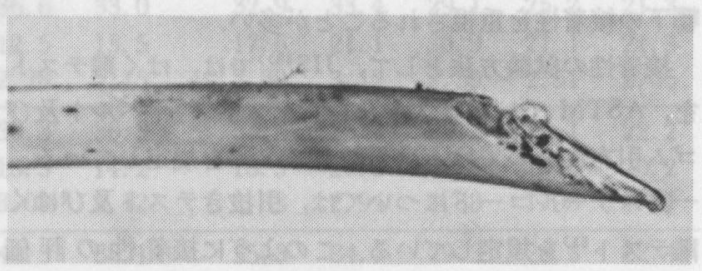

図4 疲労したタイヤから取り出したナイロンコー ドの引張破断端 
定は更に高次の解析のルートを決める分岐点である.

浸透圧法, 蒸気圧法あるいは光散乱強度法によれば, 物理的定義のはっきりした平均分子量が得られる。しか し,これらの方法は測定が面倒であったり，溶剤の選定 に制限があったりするので，測定が簡便な粘度法がもっ ぱら利用されている. 分子量の絶対值の変化を議論する 必要は実質的にはないから，ほとんどの場合極限粘度数

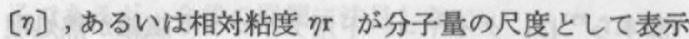
される。

表 3 は, ポリエステルタイヤコードの強度変化と対応 する分子量変化を追趾した結果の一例である ${ }^{68)}$. 接着昘 付与, 熱処理工程での強力低下は，分子量変化を伴わ ず, 微細構造変化にその原因を求めねばならない，現実

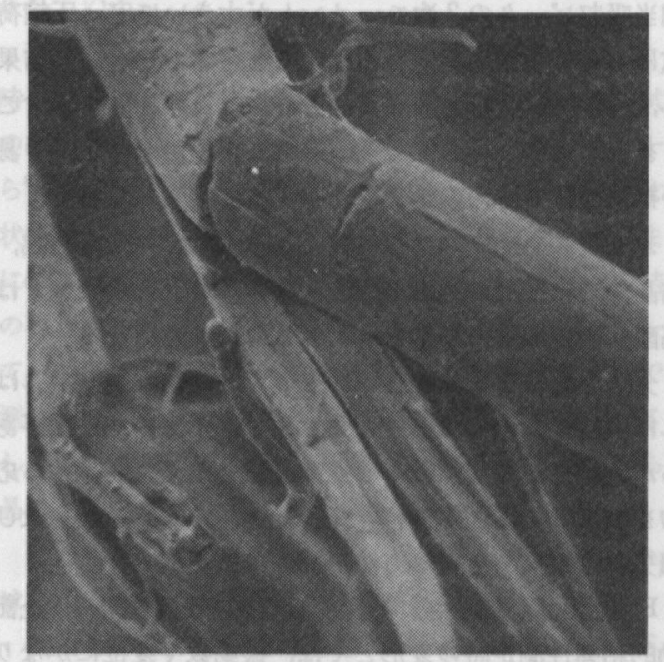

図 5 疲労したタイヤから取りだしたポリエステル コードの引張破断端

表 3 ポリエステルタイヤコードのドラム走行試験 による強力および極限粘度数 $[\eta]$ の変化

\begin{tabular}{lcc}
\hline \multicolumn{1}{c}{ コードの状態 } & 強力 $(\mathrm{kg})$ & {$[\eta]$} \\
\hline 未処理コード & 15.2 & 0.80 \\
処理コード & $14.7 \sim 14.9$ & 0.79 \\
未走行タイヤ中 & 15.5 & 0.76 \\
走行後タイヤ & & \\
クラウン部 & $14.2 \sim 14.3$ & 0.79 \\
ショルダー部 & $9.0 \sim 9.4$ & 0.52 \\
サイドウオール部 & 14.2 & \\
\hline
\end{tabular}

コード $: 1000 \mathrm{D} / 2,49.2 \times 49.2 \mathrm{~T} / 10 \mathrm{~cm}$

速度 : $60 \mathrm{~km} / \mathrm{hr}$ 距離 : $8000 \mathrm{~km}$

走行時温度 : チューブ内 $123 \sim 125^{\circ} \mathrm{C}$

$$
\text { ショルダー部 } 146^{\circ} \mathrm{C}
$$

には起こり得ない過酷な条件下のモデル走行試験後, タ イヤ各部かり取り出したコードの強力と重合度の変化を 見ると，屈曲変形及び昇温が最も大きいショルダー部の コードで明白な重合度の低下が起こっていることがわか る.

分子量分布の古典的測定法としては, 分別沈殿法があ り，最近はより簡便な GPC (Gel Permeation Chromatograph)法が広く使われるようになった. それぞれの手法 のナイロン 6 , ナイロン66纎維への応用例 ${ }^{69770)}$ が報告さ れている.

ゴム補強用纎維の性質への分子量分布の影響が問題と されることはほとんどなかったが，上記の手法の簡便化 に伴って分子量分布にまで立ち入った解析が加えられる ことも期待される.

\section{3 化学組成, 分子構造}

ゴム/繊維系で,織維そのものの同定が必要になること は少ない. 加工工程中や使用時の加水分解や熱分解との 関係において，化学組成の分析か゚行われる. ポリェステ ル及ぴポリアミド繊維で分子鎖の切断が起こると，アミ ノ基，カルボキシル基などの末端基量が増加したり，末 端基の種類が変化する. ポリエステル緎維の加水分解速 度が，カルボキシル末端基量に依存することが知られて いる. カルボキシル末端基又は，アミノ末端基の定量に は，適当な溶剂に繊維を溶解して，アルカリ又は酸で中 和滴定する方法か゚とられる.PET のカルポキシル末端基 の典型的な分析方法は, Oークレゾール/クロロホルム 混合溶剂中に繊維を溶解し，アルカリによって電位差滴 定を行ら方法である ${ }^{11}$ ポリエステル繊維のアミン分解 をフフィルム状試料によってモデル的に解析した例 ${ }^{22)}$ は, 末端に形成されたアミド基量を Kjeldahl 法及び Dumas法によるNの定量によって決定している。一般の 高分子の分子構造の解析に用いられる赤外線吸収スペク トル，紫外可視吸収スペクトルなどの分光手法が，ゴム 補強用繊維に適用されることは少ない.

(1)「暗い試料」が一般的であり，多種類の添加剂が 含まれているので，緎維だけの情報をとり出すのが困難 であったこと.

(2) 繊維の化学構造におこる変化があまり大きくなく 従来の分光手法ではスペクトルの明白な変化としてとら えられることが少ないこと.

(3) あるか゚ままの姿で繊維を分析しようとすれば, FRR の微小な部分が対象になり,従来の分光手法では安 定したスペクトルが得られないこと. などが, その理由であった。 
最近話題に登るよ5になったフーリエ変換赤外分光法 (FT-IR)によると「暗い試料」についても鋭いスペクト ルが得られ，また従来きわめて困難であった 2 試料間の 微妙なスペクトルの差を, 高い信頼性のもとに知ること

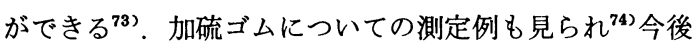
FRR の解析にも広く使われるようになるであろう.

\section{4 界面の構造に関する知見}

繊維の強度と並行して重視されるのは, ゴムと繊維の 接着強度であり，接着効果をあげるためのゴムと繊維の 間に接着剤層を介在させるのが普通である，界面のマク 口な構造と形態の観察は接着状態を論じる前提になり, 糸束内人の接着剂の浸入状態の断面顕微鏡観察, 接着破 壊試験後の試料の表面観察などによって接着状態を推論 することが行われる。

接着界面の状態を, 化学構造や化学組成分析の立場か ら調査する手段は従来きわめて弱体であり，もっぱら現 象論をつみ重ねていたと言って過言ではない.

$\mathrm{X}$ 線マイクロアナライザー(XMA)の出現により, 前 記 SEM による形態観察と同じ視野の中に, 表面に存在 する元素種の分布を視覚的にとらえられるようになった 61). 界面に金属元素が局在するような系や，無機繊維に 適した分析法である．残念ながら，重い元素を含まない 有機化合物から成る界面の分析には，電子分光手法の中 でいろいろの制限が存在して実用段階にはやや遠い.

$\operatorname{ESCA}(\mathrm{X}$ 線光電子分光)の開発が進んで，表面の構造 のつっ込んだ解析が可能になり，新しい知見が次々と出 されていることは，さまざまの分野で接着の問題に携わ る技術者にとって朗報と言えよ5 ${ }^{75776)}$ ，筆者らは FRR への ESCA の応用例の研究報告を未だ 知らないが，今 後, 多様な応用がなされることを期待したい.

\section{5 微細構造}

X線回析法は, 繊維の微細構造分析において最も人気 のある手法である ${ }^{677}$. 㵶維の微細構造の真の姿について は，未だに議論の絶えることがない段階であり，X線回 析法の結果から安易に微細構造のモデルを創作してしま うことは危険であるが，技術的な問題を解く媒介として の作業仮説を組み立てるのに有用な情報を与えてくれ る. 広角 X線回析法によれば, 結晶構造, 結晶の完全さ または大きさ，結晶の配向分布についての知見が，小角 $\mathrm{X}$ 線干涉では Void の存在や結晶, 非晶部のくり返し周 期など $100 \AA$ 前後の電子密度差の規則性に関する知見が 得られる.

複屈折は測定が容易なところから，配向の尺度として 広く用いられる。
これらの手法は，㵶維製造技術の中で多彩な利用がな されているが，FRR では応用例が少ない.ゴム補強用㵶 維はその目的から高強度, 高弾性率を要求されるので, 製系技術の極限近くまで高配向の構造が実現されてお り，かつ深い熱処理を受けていることもあって，上記微 細構造尺度の変化が極めて僅かな領域に達していること もその理由である。

藤本ら ${ }^{77)}$ は, タイヤコード用ナイロン 6 繊維が熱処理 される際に収縮に伴って起こる強力低下が X 線(002)干 涉度ピーク角から計算される(002) 面間隔及び熱処理に よる(002) 面間隔の変化との間に相関があることを 報 告 している.

\section{6 分子運動性}

藤本ら ${ }^{77}$ は, 広幅 $\mathrm{NMR}$ (核磁気共鳴吸収)の非晶部分 相当吸収ピークの 2 次モーメントが大きいほど，圧縮荷 重による疲労寿命が短かくなることを認めた. この結果 と, 上記X線 (002)面間隔が疲労寿命と良い相関を示すこ とを合わせて, 非晶部分子鎖の相互作用が弱く，動き易 い構造が疲労寿命の延長に寄与すると推論している.

ポリエステル延伸系の広幅 NMR によって, 非晶部, 結晶部, 中間部の分率と配向状態を推定した研究例 ${ }^{78}$ は 高配向度の繊維の挙動を解釈するのに参考になる.

分子運動性を反映する物性として, 動的粘弾性がしば しば議論の対象になる。ささまざまのタイプの測定法があ るが, 繊維軸方向に微小な振動変位を与えて発生する応 力を検出し, 動的弾性率 $\mathrm{E}^{\prime}$ 損失正接 $\mathrm{E}^{\prime \prime} / \mathrm{E}^{\prime}=\tan \delta$ 及び 損失弾性率 $\mathrm{E}^{\prime \prime}$ を得る方法が簡便である.

FRR 製品が使用される際受ける繰り返し変形と, 上記 動的粘弹性測定時の変形とでは, 振動数や変位にかなり の違いがあるが，実用特性との対応は比較的良いようで ある.ゴム補強用, コードの粘弾性には, フィラメント の粘弾性に加えて繊維間摩擦や接着剂層の影響が加わ る.

Willet $^{79)}$ は，タイヤコードの素材，より構造及び測定 雾囲気の温度を変えて動的粘弾性を測定し， $E^{\prime}, E^{\prime \prime} の$ 変 化のメカニズムを論じている. 小変形の場合, タイヤ中 のコードの発熱は，E"にほぼ比例すると考えてよく，繊 維の $\mathrm{E}^{\prime \prime}$ とタイヤの到達温度との間に予想通りの相関が あることが確められている80).

$\mathrm{E}^{\prime}, \mathrm{E}^{\prime \prime}$ の值を用いたモデル計算結果では，タイヤの全 エネルギーロス中の約 $17 \%$ ガコードの寄与であることが 示されている81)

藤本 ${ }^{800}$ によれば，コードの動的弾性率E'は路面凹凸の 多い道路を走行する際の床上・上下振動加速度を通じて 
振動乗心地や騒音に影響する。 あわせて，E"が大きいと 振動の減衰性が大きくなって乗心地に影響することも示 唆されている.

音速もまた動的弾性率を反映する尺度である。最 近 Postle ${ }^{81)}$ は工業用ファブリックの動的性質の最適化を行 ら際の中間的評価尺度として布地の音速分布曲線を使用 することを提唱している．まだあまり進展していない様 子であるが，今後の展開に注目したい.

\section{7 熱分析}

FRR が製造工程や使用時に受ける熱刺激は, 繊維の重 量変化をもたらすほどのものではなく，普通 TGA など の熱分析を適用することは少ない，一方，DTA，DSC などの手法を用いて相変化によって起こる熱の出入をと らえ, 繊維の内部構造变化を追跡しようとする試みがな されている.

高分子固体の融点を測定するために試料を昇温する 時, 昇温によって構造変化が起こり,「測定前」の試料 の状態を正しく反映する情報を得ることが難しい，十時 ら ${ }^{82) 83)}$ は，ナイロン纎維にアセチレンガスを拡散させた 状態で， $\gamma$ 線照射することにより，結晶状態をそのまま にして非晶相に架橋結合を導入して,DSC 測定中の結晶 の再編成を抑制する手法を確立した. この手法によっ て, ナイロン 6 の延伸直後の繊維には, 通常の測定で観 測される融点よりも数十 ${ }^{\circ} \mathrm{C}$ 低い融点をもつ結晶が存在 し，熱処理によって融点の高温側への移行，すなわち結 晶の完全化が進行することが確められた.

この手法を中心にした一連の繊維構造研究について は，川口ら ${ }^{84)}$ の総説がわかりやすい.

武山ら ${ }^{68)}$ は，上記架橋固定 DSC 法を，ナイロン6, タイヤコードの加硫時強力低下現象の解析に応用した. 図 6 は，モデル加硫によるコード強力保持率と加硫前の 処理コードの同方法による融点との関係を示したもので ある. 図7 は，原系及び加硫前の処理コードのそれぞれ 同方法による融点の関倸を示したものである．詳細は省 略するが，彼らは，既に得られている加硫時の収縮と強 度変化に関する知見 ${ }^{85)}$ と合わせて, 強力低下の原因が分 子鎖の緊張の解放によって起こる微結晶の融解と再編成 の過程にあると考えている.

\section{6. まとめ}

以上に FRR 用繊維の評価方法を概観したが，それぞ れの問題点をまとめておきたい.

纎維の一般特性は, 第 3 章に見るとおり JIS やASTM によって規格化されているものが多く，測定方法そのも

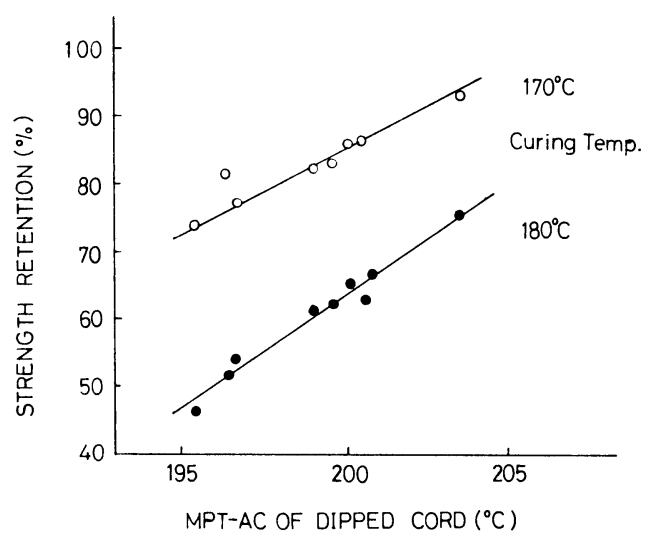

図 6 モデル加硫によるナイロン 6 コードの強力保 持率と架橋固定法 DSC 融解ピーク温度 (MPTAC) の関係

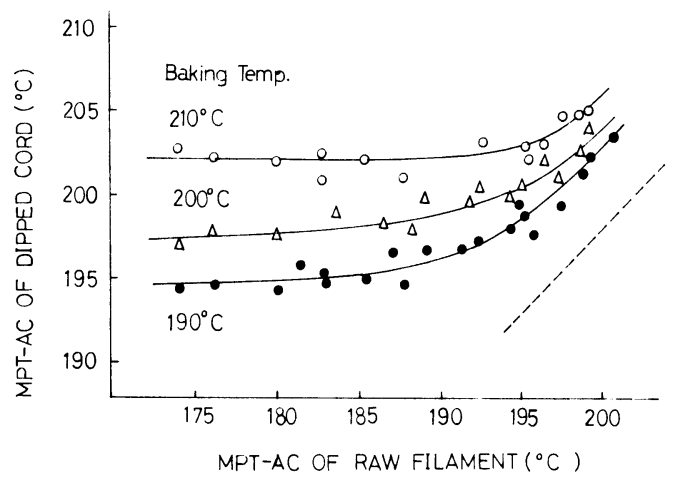

図 7 ナイロン 6 原糸及び処理コードの架橋固定法 $\mathrm{SC}$ 融解ピーク温度 (MPT-AC) の関係

のには議論に余地が少ない.FRR の特性との対応づけに 最も適した繊維特性の設定と測定方法の選定が要求され る.FRR 特性のモデル化とも言うべき接着と疲労性試験 については, 測定方法が多様であり，対象とする特定の FRR 系の使用条件下で繊維が受ける刺激を,近似的に実 現するような方法を選定しないことには，見当外れの評 価を行なら恐れがある.

一般特性とゴム中包埋状態での評価を，直接的な性能 の表現とすれば, 物理化学的分析は性能の理由づけを与 えたものであり, 性能改善の鍵になるものでる.FRR は 複雑な系であり, 分離操作なしに各成分の状態を知りた い，界面部の状態を知りたい，それらの状態の時間的変 化を追跡したい，などの現行技術の限界に近い難しい要 求がある。 これらに応える測定技術の進歩が渴 望され る. また一般に物理化学的分析用の機器は高価であり, 
FRR技術者が必要に応じて利用するのが困難なことも切 実な問題である。最近公立機関や企業の分析, 評価機能 を公開して，依頼評価に応じる動きが活発になっている のでこれを利用するのも有用であろう。

FRR 技術者としては, 既存手法に巧みな工夫をつけ加 えて，有効な情報の抽出と問題解決への結びつけに更に 努力する必要があろら。

\section{文献}

1）繊維学会編：繊維便覧原料編，丸善(1969).

2）繊維学会編：化繊便覧，丸善(1963).

3）神原・藤原編：高分子分析ハンドブック, 朝倉 書店(1965).

4）高分子学会編：高分子測定法=構造と物性, 培風館(1973)。

5) 日本化学会編：機器による高分子分析, 広川書 店(1971)。

6) E. L. Alexander（桜田，浜田，梶訳）：高分子 のX線回析，化学同人(1973)

7）角戸正夫，笠・暢民：高分子X線回折，丸善 (1968).

8) W. E. Morton, J. W. S. Hearle: Phyical Properties of Textile Fibers, Butterworths (1963)

9) T. Takeyama, J. Matsui: Rubber Chem. Technol., 42, 159 (1969)

10) T. Takeyama, J. Matsui: in Mechanics of Pneumatic Tire, ed. S. K. Clark, National Bureau of Standard, N.Y. (1971), p. 219; 同改訂版 (1978)，投稿中.

11) D. Kenyon: Proc. I.R.I., 11, 67 (1964)

12) JIS L0101-1963.

13) ASTM Standards Part 32 D 885-76

14) JIS L1017-1963, L1073-1965.

15) R. G. Aitken, et al.: Rubber World, 151, 58 (1965); F. J. Kovac, et al.: Text. Res. J., 34, 69 (1964); G. Kemmnitz: Kaut. Gummi, 12, WT270 (1957); G. Kemmnitz, et al.: Chemiefasern, 16, 182 (1966); G. Kemmnitz: J. Appl. Polymer Sci., 6, 373 (1962)；藤本枝太：繊維機械学会誌，18， 57 (1965).

16) JIS L0702-1956. ASTM Standards Part 32 D76-67.

17) R. E. Wilfong, et al.: Rubber World, 166, 40 (1972); G. E. R. Lamb. et al.: Rubber Chem. Technol., 49, 1145 (1976).

18) E. J. Powers: Rubber Chem. Technol., 47, 1053 (1974).

19) 向山鋭次：繊維機械学会誌， 20, 706 (1967)

20) W. J. Lyons: Text. Res. J., 32, 448 (1962).

21) W. J. Lyons: Text. Res. J., 32, 750 (1962).

22) 岡村勲ら：材料試験, 4, 164, 218 (1955).

23) 岡村勲ら：材料試験, 8, 75, 920 (1959).
24) W. F. Busse, et al.: J. Appl. Phys., 13, 715 (1942).

25) R. C. Waller, et al.: J. Appl. Phys., 17, 482 (1946); W. E. Roseveave, et al.: Text. Res. J., 19, 633 (1949).

26) Bradshow: ASTM Bull., 136, 13 (1945).

27) C. B. Budd: Text. Res. J. 21, 174 (1951).

28) W. J. Lyons: Text. Res. J., 40, 60 (1970)

29) D. C. Prevorsek, et al.: Rubber Chem. Technol. 44, 271 (1971)

30）神原周編：高分子の物性 I（高分子実験 学 講 座）共立出版 (1959), p. 201

31) J. W. Ballou, et al.: Text. Res. J., 28, 631 (1958)

32) N. N. Pavlov, et al.: Rubber Chem. Technol., 32, 907 (1959)

33) I. H. Hall: J. Appl. Polymer Sci., 8, 237 (1964)

34) M. N. Pilsworth, et al.: Text. Res. J., 35, 129 (1965)

35) E. W. Lothrop: Appl. Polymer Symp., 1, 111 (1965)

36) K. B. O’Neil, et al.: Rubber Chem. Technol., 41, $1042(1968)$

37) J. C. Smith, et al.: Text. Res. J., 26, 821 (1956)

38) D. R. Petterson, et al.: Textile Res. J., 30, 411 (1960)

39) J. C. Smith, et al.: Text. Res. J., 33, 919 (1963)

40) J. C. Smith, et al.: Text. Res. J., 35, 743 (1965)

41) J. W. Illingworth, et al.: Text. Res. J., 26, 243 (1956).

42) Toray Industries, Toray Tire Cord News, No. 7 (1972).

43) Y. Iyengar, et al.: Rubber Chem. Technol., 40, 442 (1973).

44) I. C. I.: French Patent 2,066,198, (1971)

45) たとえば, A. G. Buswell, et al.: Plastics and Rubber, Materials and Applications, May, 89 (1976)

46) JIS L1030-1977.

47) ASTM Standards Part 33 D 276-72.

48) JIS K6301-1975; K6302-1976; K6321-1977; K6322-1977; K6328-1977; K6330-1976.

49) ASTM Standards Part 37 D2138-72

50) ASTM Standards Part 38 D378-70

51) ASTM Standards Part 37 D 1871-68

52) P. P. Langevin, et al.: Rubber Cherr. Technol., 47, 171 (1974)

53) M. I. Dietrick, et al.: Rubber Chem. Technol., 50, 217 (1977)

54）武山高之ら：日ゴム協誌，45, 953 (1972).

55) ASTM Standards Part 24 D 885 (1967)

56) JIS L1079-1963

57) JIS K6323-1976

58) JIS D2601-1960

59) M. J. Forster, et al.: Rubber Chem. Technol., 42, 1000 (1969). 
60）小原亀太郎：顕微鏡による繊維研究法, 紡織雑 誌社(1938).

61) 谷村正満：高分子, 24, 98 (1975).

62) R. G. Patterson, R. K. Anderson: Rubber Chem. Technol., 38, 832 (1965).

63) R. G. Patterson: Rubber Chem. Technol., 39, 1382 (1966)

64）宮本宗一，鷲見保俊，藤本典秀：日ゴム協誌， 38, 48 (1965).

65）宮本宗一ら：日ゴム協誌，39, 511 (1966).

66）石崎舜三，蔵本直哉，大沼紀幸：綫学誌，25, $347(1969)$.

67）藤本枝太：加工技術，1968年 3 月号，p. 39

68）武山高之, 日聖昌夫 : 第 6 回関西繊維セミナー ・テキスト(1973).

69) M. A. Dudley: J. Appl. Polymer Sci., 16, 493 (1972)

70) A. K. Senguptz, R. K. Singh, A. Majumda: Text. Res. J., 44, 155 (1974)

71) M. J. Maurice, F. Huizinga: Anal. Chim. Acta, $363(1960)$

72) 山崎・，砺波宏明：繊学誌，31, T395 (1975)
73) 田中誠之：化学の領域, 31, 510 (1977).

74) DIGILAB 社パンフレット

75) 前田浩五郎：高分子, 26, 776 (1977).

76) 添田房美, 石谷昫 : 日本化学会秋季年会, 特 3 , p 11 (1975).

77）藤本邦彦，福田草爾：日本ゴム協会年会, 1968 年 5 月, 福岡.

78）植月正雄, 藤原鎮男 : 高分子の NMR 化学増 刊, 57, p 191, 化学同人(1973).

79) P. R. Willet: J. Appl. Polymer Sci., 19, 2005 (1975).

80) 藤本邦彦：㵶維工学, 21, 667 (1968)

81) R. Postle: 61st Ann. Conf. Text. Inst., Rotterdom (1977).

82）十時稔，川口達郎：高分子 論 文 集, 31, 106, 427 (1974); 32, 112, 363 (1975)

83) M. Todoki, T. Kawaguchi: J. Polymer Sci., Polymer Phys. Ed., 15, 1067, 1507 (1977)

84）川口達郎, 十時稔 : 繊学誌, 34, 11 (1978)

85) Toray Tire Cord News, No. 5 (1968); No. 6 (1969)

86) 今村純次 : 第 9 回関西繊維セミナー(1978).

\section{H1101073}

\section{海洋の富を求めて}

Angling for the oceans' riches

化学会社が海中農場に世界で初めて進出したのは, 注 意深く飼育したサケやマスに喜んで割増し金を支払う美 食家に対してであった。 しかし水産研究者の眼は基本的 な市場一家畜の安い飼料を求める農業者, 安価で豊富な 燃料源と食糧源を求める産業と消費者一とに向けられ た.

海中農場の大きな部分は, 海草などの海産植物によっ て成り立っており，その生育に適する条件，収穫技術，

植物から燃料や化学物質を得る方法に難しさがある。食 糧および飼料の場合は関係官庁の厳密な安全基準に挑戦 しなければならない.

海中農場がまず魚の飼育から始ったことは，海産植物 の商品生産にまつわる障害を思い合せると無理のないこ とと思われる。たとえば Union Carbide 社の Domsea Farms 社では, サケとマスを特殊な囲い中で養殖した.

Domsea Farms 社は，当初は成魚を料理店へ販売してい たが，今では小売レベルで消費者へ市販することを試み ている. ふ化についても検討しているが，サケの幼魚の 回帰率が問題となる.
魚と対照的に海産植物はまだ市販を目的として栽培さ れたことはない．化学産業ではすでに食品製造用のキサ ンチンガムを海草から取出しているが，基礎的化学原料 物質または然料として継続的には海産植物を利用してい ない，海草の食品的価值については，必要なたんぱく質 を多く含むにもかかわらず，商業ベースへの道が開かれ ていない

Giant California Kelp(Macrocystis) は大きなかっ色の 海草であり，カリフォルニア州の海岸に漂っており，成 長がはやくて収穫が容易であり，炭水化物に富み，発酵 や化学処理によって然料や化学製品の重要な中間物とな る.この植物が注目され，その海中農場における栽培は Ocean Energy and Food Farm Project が担当し，米国ガ ス協会 (American Gas Association) が後援している.

その他の会社でも研究が行なわれており，Macrocystis のけん気的消化によるメタンガスへの転換に成功した. この海草中には糖やアルギン酸塩などが含まれており， 栄養価は動物におけるムラサキウマゴヤシに匹敵する. そのほか，Spirulina と呼ばれる青緑色海草もたんぱく 質源として検討されている。写図 1

B 258 A Chem Week 120 [18] 26, 28, 30 (May 4. '77)

〔日本科学技術情報センター 発行「海外技術ハイライト」より 転載許可第文一12号] 